\title{
Ethical Principles of Journalism: Content Analysis of the Covers of Most Read Daily Newspaper in Croatia
}

\section{Pavelin Goran}

PhD Department of Tourism and Communication Studies, University of Zadar

\section{Marijana Karamarko}

MA in Journalism and Public Relations

Doi:10.5901/mjss.2015.v6n4s2p141

\begin{abstract}
The subject of this research is the ethical dimension of the print media. In an effort to attract as many readers, editors of daily newspapers often use any means available. We are witnessing the phenomenon of sensationalism, distortion, manipulation. Such deviations in journalism distort perception and leave no space for critical and independent judgment of the surrounding society. The main aim of the research is to determine the ethical controversies on the front pages of the most read daily newspapers - Večernji list, Jutarnji list and 24sata. 1053 headlines from the mentioned newspapers were analyzed using both qualitative and quantitative analysis. The survey included the following categories: false reporting, unbalanced reporting, unbiased reporting, absence of social responsibility of the media, manipulation of the readers, news selection, violation of rights to privacy, violation of the criteria of decency, obscenity and bad taste. The research results confirmed that the analyzed newspaper covers violate ethical and professional principles of journalism. Slightly more than $5 \%$ of the headlines published on the front pages of all these newspapers contained information whose truthfulness was questionable. Most biased headlines were published by 24 sata. The same newspaper published most irrelevant and useless information. Bad news prevailed in more than $50 \%$ headlines of the analyzed newspapers. Most headlines which violate the right to privacy, as well as the headlines that do not comply with the criteria of good taste and decency were published by 24sata. The survey shows that there are significant differences in the quantity, type and severity of ethical controversy between Jutarnii list, Večernii list and 24 sata.
\end{abstract}

Keywords: ethics of journalism, ethical controversies, daily newspapers, headlines

\section{Introduction}

The time we live in is marked by the widespread lack of ethics which has unfortunately infected the media, and the press. Ethical dimension of the print media is the subject of this study. In an effort to attract as many readers, editors of daily newspapers often use any means. So the headlines of the daily newspapers are often full of sensationalism, trivial news, scandals, crime, obscenity, etc. In this way, editors, attracting readers, disregard professional and ethical principles of journalism. These contents of front pages are indicator of negative trends in journalism, which significantly affects the decline of the credibility of newspaper as a medium, and thus causes long-term damage to the company. The main role of newspaper as a medium, to inform in an objective and balanced manner is neglected.

The media owners, editors and market laws affect the credibility of the media and incite the increasing violation of professional and ethical standards of journalism. We are witnessing the phenomenon of sensationalism, intentional or accidental distortion, excessive thematization of crime, tabloidization and manipulating the readers. These deviations in journalism distort perception and leave no space for an independent, critical and free judgment of society and he world around us.

Truthfulness, fairness, accuracy, balance and neutrality are professional standards without which there is no quality journalism, and without ethics there is no quality or professional journalism. An indispensable concept in discussions on the ethics of journalism is social responsibility of journalists, which implies that a journalist needs to serve responsibly to the individual and to society as a whole. In addition to the responsibility of journalists, discussions on responsibility of the recipient of media content are more frequently. Are the recipients just passive "victims" or should they through their own engagement contribute to better journalism. How can the relations and rules in journalistic profession be regulated more effectively? One possible way is quality legislation, but despite the laws, regulations and codes of 
ethics, which by their rules seek to regulate the ethical dimension of journalism, we are witnessing a violation of professional rules and ethical principles. As the best way of regulating the profession, media theorists frequently point out self-regulation.

The main goal of this research is, based on the analysis of the covers of the most read daily newspapers in Croatia, to prove that the content of covers deviates from ethics and professional standards of journalism. The aim is to indicate ethical controversy on the front pages of the most read daily newspapers. Our goals were to point out the fact that the editors of covers do not care about the standards of truthful, fair, impartially and balanced reporting; to point out the fact that, while selecting the content of covers, the editors neglect the importance of information and usefulness for the society; to point out the fact that the front page is dominated by bad content, which means that, for editors, bad news is good news for editors; and to point out the fact that the content of covers violate the criteria of decency, good taste and privacy.

To simplify, in this research we want to synthesize historically current, but also more recent theoretical premises of Croatian and other international media experts who write on media ethics and to conduct the analysis(qualitative and quantitative analysis of headlines- in which we found some of the ethical controversies) of national newspaper covers in Croatia. The unit of analysis is the individual headline in most read daily newspapers in Croatia - Večernji list, Jutarnji list and 24sata, on a sample of three months. By "headline" we mean headline, banner headline, sub-headline and accompanying photo. Based on the results obtained in this research we can recognize the current (lack of) ethics which dominate Croatian media scene. The contribution of this research can generally be useful to the scientific community that deals with media research and to numerous employees of media companies in review of their own professionalism.

\subsection{The role of headlines}

Newspaper, as the oldest mass medium, survived the appearance of radio, television and interactive media, and other media which still largely influence the attitudes and beliefs of readers. McLuhan (according to Zgrabljić-Rotar, 2007:78) says that people do not read newspapers but rather that they immerse themselves in them as in the hot bath. Front pages of print media really invite people to "dive into that hot bath". To encourage the reading, headlines should be provocative, says Silić (according to Petriševac, 2009: 37) and writes that therefore "the words used in headlines are strong and convincing, they are paraphrases of proverbs and sayings, the proverbs and sayings themselves (close and understandable to the readers' experience), irony, contrast, paradox and similar figures, dialectal or local words and phrases, jargon, different puns - everything which impacts the feelings and therefore induces the interest of the reader."

Creators of media content and thus of the headlines, are great connoisseurs of man, the anthropological and psychological tendencies of mankind; they know how to formulate the headlines to attract readers. By this we mean first of all the well-known tendency of man to be destructive, as well as the fact that sensationalism and trivia preoccupy human perception stronger than positive content or content whose understanding requires certain intellectual effort.

Ivas (2004: 25) argues that "a bad text with a good headline is more likely to be read than a good text with a bad headline". If we agree with Ivas's statement that "a bad text with a good headline is more likely to be read then a good text with a bad headline" we can conclude two things. First of all, it is very easy to work on attracting human attention, i.e. inducing emotions. Secondly, the content or quality is less important to the readers. We can conclude that "emotional moment" is beyond the rational. Therefore, in shaping the headlines and in effort to sell their newspapers, the creators of the front pages should bear in the professional and ethic principles of journalism, which are based on reason rather than on emotions.

\subsection{Professional standards of journalistic reporting}

Every human activity, if it wants to be in the service of common good, must be based on professional and ethical standards. These standards are so important that they are often prescribed by legislation, because in their desire for a speedy material gain, people tend to ignore the ethical and professional rules of their profession. Journalism, which influences the broad masses of people (affects their views, opinions, perceptions, emotions, etc.) should be an activity whose imperative is the concern for the common good, through professional principles.

In 1954, The International Federation of Journalists adopted a declaration which prescribes the rules of professional decency:

Respecting the truth and the public right to the truth is the first obligation of journalists. A journalist, in recognition of this commitment, defends the principles of freedom and the right to comment and critique, while finding and reproducing the news properly. A journalist reports only the facts obtained from a trustworthy source, he does not suppress important 
information and he does not falsify material. He only uses fair methods to find information, photos and other materials. In case he accidentally publishes news which later prove to be wrong, he will correct it (according to Kunzik, Zipfel, 1998: 83-84).

Although it has been more than sixty years since the Declaration was adopted, these published rules are still universal and actual. Why is the principle of truthfulness important? To answer this question we can start from the personal level, the journalists themselves. If a journalist, in his work, violates the principle of truthfulness consciously, he endangers his own internal journalistic freedom, and therefore his journalistic creativity, two important preconditions of being a good journalist. In addition, by disrespecting the principle of truthfulness, in long term the journalist harms the press company he works for, despite the current material welfare achieved by such journalism. However, most of all, he harms the readers, because the journalism which intentionally violates the principle of truthfulness can cause negative emotions, form false attitudes, create harmful social divisions, ideological blindness and distrust towards the media in general. In this way, a journalist may harm his colleagues too, because people tend to create stereotypes, so we can often hear that "the newspapers lie".

Elisabeth Noelle-Neumann and Winifred Schultz (according to Kunzik, Zipfel, 1998:85) include the awareness of responsibilities, the protection of internal and external independence, commitment to human rights, tolerance towards the other and different, respect for the truth, keeping professional secrets, respect for privacy, avoiding discriminatory criticism, violence and immorality, and the level of education of journalist that corresponds to the level of his responsibility, in the basic professional standards of journalism, Integrity is also one of the important professional standards. Integrity is a category introduced in journalism by Bennet (according to Malović, 1997: 158-159). For Bennet, the notion of integrity means that a journalist should collect as much information as possible, trying to show all sides equally, with their commentaries and interpretations, while integrity points more to the good intentions of a journalist rather than to the objectivity.

The time we live in can be characterized as a time of pluralism of opinions, ideas, points of view, political and ideological divisions, as well as a time of democracy and personal freedom, which is why it is especially important to respect the principles of journalistic integrity. In the multitude of conflicted opinions, it is necessary to give everyone a chance to express their own views, so the readers, viewers and listeners could have the possibility to rationally evaluate the media content. It is quite understandable that in their private lives journalists can be ideologically and politically allocated, and that they can have their own points of view, but it certainly should not be seen in their professional work. By expressing preference or taking sides, the reporter could suggestively affect the audience, leaving no space for freedom, necessary for forming their own views, opinions, beliefs and orientations. For those who are able to recognize when a journalist is bias, it can cause negative emotions and distrust towards journalists and journalism as such, because the task of a journalist is not to impose their own opinions, but to present an impartial journalistic piece of work. Therefore, we can equate the disrespect for the principle of impartiality with the disrespect for readers. In this way, in the end everyone loses: a journalist and the company which he works for both lose their credibility, and the audience loses the right to impartial information, which is a precondition for freedom to form own beliefs. Explaining media partiality, Street (2003:16) in his book Mass media, politics and democracy highlights the image distortion and the corruption of the world democratic process as a fundamental problem of media partiality: "If the media promote some interests systematically and inform citizens incorrectly, the democratic process will not work effectively. When faced with favoritism, media critics express their fear that a misrepresentation or preference of one side has important consequences for the way people think about themselves, the way others think of us, the outcome of the political process and the democratic practice."

We are witnessing a phenomenon where journalists, guided by ideological preference, often unwisely, but often also intentionally, confuse opinions with comments and facts. Although we must admit that it is difficult to be completely objective and impartial, journalists in their own journalistic work are not allowed to express outburst of emotions or ideological, political or any other preference.

"Mass media have the power of persuasion, and they are able to expand their own interpretations of reality" claim Kunzik and Zipfel $(1998: 53,57)$ and conclude that "it is only when an individual receives sufficient information on the decisive questions and decisions, that he or she is able to participate responsibly in the creation of public will."

We live in a time of fierce competition between press companies.

In a struggle for survival on the market, the editors often violate the basic principles of professional journalism, giving priority to the news with the highest public interest. Therefore, more and more attention is given to sensationalism, disasters, gossip, scandals, crimes, etc. The important question is whether it is even possible for press companies to have balanced journalistic reporting and to survive on the market. 


\subsection{Ethics in Journalism}

Any human activity requires certain rules of behaving and acting. Journalism is not an exception. If we start from the assumption that a man is inclined to violate the rules and regulations in all areas of his activity and to misuse his own freedom, it should be said that the human action through the media is not an exception to such occurrences. The media create our reality and have the possibility to strongly influence on people. Therefore, the ethical principles should be at the top of the priority list of the journalistic profession.

According to Hanson ${ }^{1}$ : «Media ethics draw on a range of philosophical principles, including basic Judeo-Christian values, Aristotle's ideas about virtue and balanced behaviors (the golden mean), Kant's categorical imperative, Mill's principle of utility, Rawls's veil of ignorance, and the Hutchins Commission's social-responsibility ethics».

Frankena (1998: 3, 34, 35) defines ethics as a "philosophical reflection on morality, moral problems and moral judgment" and talks about the two main principles of morality. These principles include the principle of welfare or utility and the principle of justice. These two principles tell us how to increase the total amount of good in the world and how to determine what is right in certain circumstances, as opposed to what is wrong. Pope Wojtyla (1998: 19-20) in The Foundations of Ethics, writes that ethics as a discipline approaches the moral life in a normative manner. This means that ethics determines the norms, judges what is evil and what is good, and explains and demonstrates why it is so. The definitions of ethics includes always the notion of morality and moral principles. Bertrand (2007:26) says that the morality is the intimate ethics of each individual, their sense of duty, based on personal point of view and life experience.

The notion of ethics is also connected with the notion of responsibility. The ethics of responsibility, as Max Weber writes (according to Vilović, 2004: 10) "dictates of a man to be aware of the consequences of their moral views and acts." Kunzik and Zipfel (1998: 79) believe that journalists follow the ethics of persuasion, and that they refuse to take responsibility for the consequences of their own actions, but the writers point out that, at the same time, it remains unclear what it means to take responsibility.

Aristotle (according to Frankena, 1998: 56) believes that the individual is responsible for his act only if "the cause of the act is internal, i.e. if the act is not forced by somebody or something external upon the individual, and if his action is not the result of ignorance which is not a consequence of his earlier choices."

According to Bertrand (2007:10) the ethics of the media does not belong to the domain of law, or the domain of morality in the narrow sense, but it is this that media should perform an important social function. Explaining the ethics of journalism, Patterson and Wilkins (according to Vilović, 2004: 15) introduce the concept of ethical discernment. Elements of ethical discernment are: respect of the dignity of person we write about, treating others the way you would like others to treat you, prediction of adequate data on important subjects, accuracy, resistance to arrive equally to all sources, fairness towards all sources and reporting appropriate and fair about all segments of society. Unfortunately, although the issue of media ethics at the formal level has been settled in laws, rules and codes, the implementation is absent in practice. One may wonder why is this so? Despite all possible pressures on journalists by editors, owners, political and ideological groups, etc., it should be noted that the causes of the lack of ethics should be sought on a personal level of journalist. Above all, we think of problematic, i.e. conformist attitude of journalists towards the truth, justice and human in general.

According to Stephen J.A. Ward ${ }^{2}$ the aims of journalism ethics are: «understanding - deepen our understanding of journalism's ethical functions and its principles; ethical reasoning- improve the ethical reasoning of journalists, reforming re-define existing standards and construct new ones; promoting - promote ethical behavior and decision-making in news media and discussion - promote public discussion of journalism ethics.

\subsection{Social responsibility}

The media have become one of the most important factors of socialization. The authors which call the media "the fourth estate" or "the fourth power" speak about the power of media. Because of its important social role and because of its large influence on public opinion and social processes, social responsibility of the media is one of the key concepts in the discussion on ethics of journalism.

Declaration of UNESCO International Principles of Professional Ethics in Journalism (according to Malović, 2007:

\footnotetext{
${ }^{1}$ Hanson, E. Ralph., (2014), Chapter 14. Media Ethics: Thruthfulness; Fairness, and Standards of Decency. [Online] Available: http://www.cqpress.com/docs/college/Hanson\%204e\%20Mass\%20Com\%20CH\%2014.pdf (May 10, 2015)

2 Ward, Stephen, J.A., (2015), Global media Ethics. University of Wisconsin: Center for Journalism Ethics. [Online] Available: https://ethics.journalism.wisc.edu/resources/global-media-ethics/(May 10, 2015) 
77) specify the social responsibility of media: "In journalism, information is understood as a social good, and not as a commodity, which means that the journalist has a responsibility for the transmitted information, and therefore he is responsible not only towards those who control media, but finally, towards broad public, including various social interests. Journalist's social responsibility requires that he acts, under all circumstances, in accordance with his personal conscience.

Besides the social responsibility of the media and journalists, in recent times we can listen frequently about social responsibility of the recipient of media content. Are the readers, viewers and listeners (and can they be) responsible for the negative trends in contemporary journalism? Should they be considered only as "victims" of the media or as active participants in media communication process? When talking about the responsibility of the recipients of media content, it should be noted that it is not possible to consider all the recipients as responsible. Because of the lack of experience, education and cognitive abilities, a large number of recipients is not able to recognize the lack of professionalism in the media. Therefore, they are justified of responsibility because of ignorance. On the other hand, those who can be held responsible (educated, politically and social engaged, academic and religious communities, civil organizations) should contribute to better journalism by their engagement, constructive criticism, appeals and warnings.

Journalism is a specific activity, so there is a question can it be regulated like other professions? If we try to answer this question, we can say that, although the media is regulated by laws, codes and recently, by self-regulation, there is always a tendency of journalist, editors and owners to look for ways to trick or bypassed all of the above to achieve their own objectives, material or ideological. Because of this tendency, the care about the respect of the laws and ethical principles in journalism should be a constant concern of legislative, executive and juridical authority as well as the general public.

On the website ${ }^{3}$ of Wisconsin University's Center for Yournalism Ethics, Stephen J.A. Ward speaks about the notion of global media ethics. Author cites two reasons for introduction of global media ethics: « practical - a non-global ethic is no longer able to adequately address the new problems that face global journalism, and ethical - new global responsibilities come with global impact and reach.»

\subsection{Ethical controversies in contemporary journalism}

Media content are frequently such that it can be said that there is degenerate humanity devoid of all moral, esthetic and other positive human qualities, behind them. The impact of such content on a man is very difficult to consider critically, especially the impact on the psychological component, because of the human nature which is a mystery despite enormous human knowledge in this field. Realizing the right to information requires should always be in due time, accurately and impartially, and in respect for the moral and positive laws, and in the end, in respect for the human dignity in finding news as well as in their spread. Anyone who takes a critical look back on the front pages of the daily newspaper that "scream" by sensation, evil, bizarre and trivialities, will know that the contemporary media are far away from these principles. To inform, to entertain, to educate - these would first come to mind when one would be asked to name the three basic functions of the media. However, the content of contemporary media lately serves only to entertain, to shock, to entice - and the basic functions seem to have reduced to this. We are witnessing a drastic decline of the credibility of media. Regardless of all difficulties that journalists experience every day in their work, there should not be justification for unethical journalism, because of its crucial importance for the society as a whole. If journalism as such does not contribute to the common good, that is to a human, it is a bad journalism that needs to be recognized and sanctioned. It is important to not proclaim journalists as "evil" persons, but to talk about their work critically, for their own good, for the good of their profession and the society.

\subsection{The market: imperative and risk}

When we talk about the mass media, especially the print media, we can't and must not ignore the commercial side which enables the existence to the people in the journalistic profession. It is quite clear that the newspapers are printed to be sold. Like most other products, the newspapers have become the product exposed to the merciless market battle, which marks the era we live in. However, it must be wondered whether the newspaper is the commodity like any other? Should the media market set different criteria, criteria which would include ethical dimension? Commercialization is the constant

${ }^{3}$ Ward, Stephen, J.A., (2015), Nature of Journalism Ethics.//Research ethics/. Center for Journalism Ethics School of Journalism \& Mass Communication: University of Wisconsin - Madison. [Online] Available:http://www.journalismethics.info/research_ethics/nature_of_ journalism_ethics.htm (May 10, 2015) 
threat to journalism. To survive on the market, the journalism must harmonize the market value and the service to the common good. Unfortunately, we are witnessing the fact that in a bid to survive on the market there is no ethical dimension, and thereby, the fundamental task of the media - truthful, accurate, impartial and balanced informing - is threatened.

Bauer (2007: 117) warns that market mechanisms are changing journalism from a system of social cooperation into routine of production the artifacts to saturate the market needs. König, the president of European Federation of Journalists (according to Vilović, 2011: 82), claims that the crisis of journalism is a crisis of profit, because the media owners want profits. Bertrand (2007: 8) also blames media entrepreneurs and says that, to them, the information is material by which they exploit consumers, and try to maintain the established order which is profitable to them.

The process of globalization has brought different trends in a small country like ours, and one of these trends is tabloidization. We can say that the tabloidization process has found the fertile ground in Croatia. The transition from the one-party system, in which the media were controlled by the government, to the multi-party system, in which the freedom of media is almost absolute, had negative impacts on contemporary journalism. Vilović (2004:35) sees the tabloidization in Croatia as a result of poverty and low level of education. While this is partly true, we would not be able to completely agree with this statement. If the two mentioned conditions are preconditions for appearance of tabloidization, then the Western countries, whose level of education is much higher than ours and material wealth is incomparable whit ours, would be excluded from this phenomenon. We are witnessing that the tabloidization has appeared on the West, where it is much developed than in our society. Perhaps we should search for the causes in the fact that our society is obsessed with Western culture and in the fact that our society has an aspiration to be the West. Also, we can search for causes in public fascination for powerful, rich, famous and successful people. Besides tabloidization, we can mention the media manipulation as the other negative phenomenon in contemporary journalism. Although the media manipulation has a long history, today it is brought to the perfection and this is the greatest danger. As in all social relationships which may cause the damage for the individual as well as for the society, in the relationship between the media and the recipients of media content, there is often a distortion of reality, or hiding the truth consciously or unconsciously. Noelle-Neumann emphasizes (according to Labaš, Grmuša, 2011: 98-99) that "manipulation exist when trying to influence people without their knowledge, with studied knowledge about how to control their will. If this succeed to induce the acceptance of the attitudes and actions which would not be accepted by their own will, recipients becomes unfree object of manipulation.

In their strategies of manipulation, the media misuse human weaknesses and imperfections or the man's tendency to accept media content "for granted", without criticism and without the use of the rational component. In doing so, the media want to provoke an emotional response, both positive and negative. If they succeed to attract man's emotional level, they get him for "their own thing", since it is known in the psychology that the emotions initiate the action and distort the perception. The media manipulation is not an innocent phenomenon. It is not only harmful for an individual, but it is capable to cause serious consequences for the whole society.

\subsection{Most read daily newspapers in Croatia}

According to the Croatian Chamber of Economy, the most read daily newspapers in Croatia are: 24sata, Jutarnji list and Večernji list.

Table 1. Edition of the most read daily newspapers in Croatia (source: Croatian Chamber of Economy)

\begin{tabular}{|l|l|c|c|c|}
\hline Publisher & Publication & Edition in 2011 & Edition in 2012 & Edition in 2013 \\
\hline EPH Media Itd. & JUTARNJI LIST & 63.901 & 58.348 & 50.582 \\
\hline Večernji list Itd. & VEČERNJI LIST & 71.658 & 62.494 & 52.627 \\
\hline 24sata Itd. & 24 SATA & 145.440 & 125.194 & 108.354 \\
\hline
\end{tabular}

Most read daily newspaper, 24 sata, is published by 24 sata Ltd., a company which is wholly-owned by Austrian Styria. The first edition was printed in 2005.

Večerni list is almost wholly owned by Austrian Styria. This newspaper was first published in 1959.

Jutarnji list exist since 1998, and it is owned by Europe Press Holding and German's WAZ (Westdeutsche Allgemeine Zeitung). 


\section{Methods and Research Objectives}

The subject of this research is to analyze the ethical controversy on daily newspapers' front pages. We will explore the number, types and trends of ethical contradictions in headlines. In the study, we will use the method of content analysis. We will analyze the content on front pages of must read daily newspapers in Croatia: Večernji list, 24sata and Jutarnji list. In the selection of the daily newspapers, the only criterion was the edition. The fact that these newspapers are the most read indicates that they have the greatest impact on an individual and on the society. The unit of analysis is the individual headline. Under the notion of headline, we mean headline, banner headline, sub-headline and accompanying photo of above mentioned daily newspapers. We will analyze the front pages on a sample of three months, which are March, April and May 2014. It means that the research includes a sample of 259 editions ( 85 of Večernji list, 89 of Jutarnji list, and 85 of 24sata).

The objectives of this paper are:

- to point out the fact that the editors of front pages do not take care about the standard of truthful, fair, impartial and balanced reporting;

- to point out the fact that the editors of front pages, while selecting the content of front pages, neglect the criterion of importance and usefulness of information for the society;

- $\quad$ to point out the fact that the bad content prevail on the front pages - a bad news is a good news for the editors

- to point out the fact that the contents of the front pages violate the criteria of decency, good taste and privacy.

\section{The Results of Research and Discussion}

For the purposes of this research we analyzed 1053 headlines (424 from Jutarnji list, 467 from Večernji list and 162 from 24sata). Considering to the first mentioned objective of the research, we focused on the following categories: false reporting, unbalanced reporting, impartial reporting and unfair reporting. By the analysis of front pages we find out that 60 headlines (of 1053 analyzed in total) could be considered controversial from the aspect of truth. The most controversial headlines according to this criterion are published by Večernji list, 26 in a total, Jutarnji list published 25 of those, and 24sata 9.

Table 1. Ethical controversial headlines from the aspect of truth in particular daily newspapers

\begin{tabular}{|c|c|c|c|}
\hline Daily newspaper & Jutarni list & Večernji list & 24 sata \\
\hline Total number of headlines & 424 & 467 & 162 \\
\hline Ethical controversial headlines & 25 & 26 & 9 \\
\hline SHARE & $5,9 \%$ & $5,57 \%$ & $5,56 \%$ \\
\hline
\end{tabular}

Although the obtained percentages of ethical controversial headlines are relatively low, they are certainly not negligible, primarily because of the fact that the principle of truthfulness is fundamental precondition of professionalism in journalism. The headline is a form which is memorable and suggestive, and therefore has a great impact on the recipients of the message. If the headline is untrue or partially true, it can influence on the recipient in such a way that he creates the wrong attitudes, beliefs and opinions based on the false information.

Next category we explored is unbalanced reporting. According to the previously mentioned concept of "balanced programming" from the American journalistic practice, which means that all topics in the media should get equal attention, regardless of their popularity or unpopularity, in this category we explored the prevalence of specific topics on the front pages. According to the perceived frequency of topics, we determined twelve categories: domestic politics, foreign policy, economy, judiciary, education, culture, health, religion, sports, show business and crime. All the other topics which are also recorded on the front pages, but in a negligible number, we classified under the category of "other". In analysis of front pages we received the following information: in the must read daily newspapers, the most frequent headlines are related to: issues of domestic policy at $28,87 \%$, crime at $9,69 \%$, foreign policy at $9,21 \%$, show business at $7,79 \%$, sports at $7,31 \%$, economy at $7,22 \%$, judiciary at $4,08 \%$, health at $3,89 \%$, culture at $3,80 \%$, religion at $3,42 \%$ and education at $2,18 \%$. Topics classified in the category of "other" are represented with a share of $12,54 \%$ of headlines. 
Table 2. Number of headlines according to the topics

\begin{tabular}{|c|c|c|}
\hline Headline topic & Total number of headlines in all newspapers & Share \\
\hline Domestic policy & 304 & $28,87 \%$ \\
\hline Other & 132 & $12,54 \%$ \\
\hline Crime & 102 & $9,69 \%$ \\
\hline Foreign policy & 97 & $9,21 \%$ \\
\hline Show business & 82 & $7,79 \%$ \\
\hline Sports & 77 & $7,31 \%$ \\
\hline Economy & 76 & $7,22 \%$ \\
\hline Judiciary & 43 & $4,08 \%$ \\
\hline Health & 41 & $3,89 \%$ \\
\hline Culture & 40 & $3,80 \%$ \\
\hline Religion & 36 & $3,42 \%$ \\
\hline Education & 23 & $2,18 \%$ \\
\hline Total & 1053 & $100 \%$ \\
\hline
\end{tabular}

If we look at the proportion of headline according to the presence of topics in a daily newspapers, first thing we notice is that crime section and show business prevail on the headlines of 24 sata, which indicates the characteristics of tabloid newspapers, but we must ask the question, whether the crime section in general should take place on the front pages of any daily newspaper, including the tabloids? Also, the troubling fact is that in Večernji list and Jutarnji list nearly all topics, except the political ones, are represented with the proportion of less than $10 \%$.

When analyzing the balance on newspaper front pages we didn't limit ourselves only to recount the representation of certain topics, but also to the way in which these subjects are "offered" to readers. Headlines with political and crime topics occupy the central position of the front pages and they are incomparably larger, more prominent and richer in content than other headlines.

The following criteria we investigated is the criteria of impartiality. Impartiality means that the journalist may not take sides, that is necessary in media reporting to clearly separate opinions from facts, and that the reporting should be cool-headed, not emotional. By analyzing the headlines, it was quite difficult to determine headlines that violate the principle of impartiality, primarily because it was necessary to approach the analysis of texts for more complete analysis of impartiality. The headlines, because of their form do not provide a complete insight into the possible violation of the above criteria, which does not mean that in the analysis we cannot come to some conclusions that point to a violation of the principle of impartiality. Thus, from a total of 1053 analyzed headlines we have selected 227 , or $21.56 \%$ of headlines that we could define as biased. In these headlines, facts are not separate from opinions, headlines are emotionally "colored", and people who are called in these headlines are not accessed in an impartial manner. Večernji list published a smallest number of these headlines, 19 of them or $4.07 \%$. Jutarnji list published 52 biased headlines which is $12.26 \%$, while the daily 24 sata published 56 of such headlines or $34.57 \%$.

Table 3. Headlines according to the criteria of impartiality

\begin{tabular}{|c|c|c|c|}
\hline Daily newspapers & Jutarnji list & Večernji list & 24sata \\
\hline Total number of headlines & 424 & 467 & 162 \\
\hline Biased headlines & 52 & 19 & 56 \\
\hline Share & $12,26 \%$ & $4,07 \%$ & $34,57 \%$ \\
\hline
\end{tabular}

The concept of integrity is used in journalism instead of the concept of objectivity. When we speak of the principle of integrity, we can say that it involves a true, balanced and unbiased reporting. So, journalistic reporting that is untrue, unbalanced and impartial cannot be considered as a fair reporting. As we already handled mentioned categories in the previous part of the research, in the following, we will focus on the credibility and objectivity. One of the ways in which we can determine whether some newspapers are objective and credible is the source. Although insisting for specifying sources on the front pages might seem like an exaggeration, we can say that the headline without mentioning the source can cause completely different connotations. Večernji List has the most published sources of information on the front pages. Večernji List published sources of information in $36.18 \%$ of headlines, percentage of publishing sources of information in Jutarnji list is $29.95 \%$, and the smallest number of sources of information was published by the newspaper 24 sata, only $8.64 \%$. 
Table 4. Specifying sources

\begin{tabular}{|l|c|c|c|}
\hline Daily newspapers & Jutarnji list & Večernji list & 24sata \\
\hline Total number of headlines & 424 & 467 & 162 \\
\hline Share of headlines with sources & $29,95 \%$ & $36,18 \%$ & $8,64 \%$ \\
\hline
\end{tabular}

Although with the analysis of texts we would receive more reliable information on the labeling of sources of information, it should be noted that the data presented in Table are relatively satisfying (with the exception 24sata) considering that we analyzed headlines. The headlines are not the most appropriate criterion for confirmation of the authenticity of some information. Also, not quoting sources in the headline does not mean that in the text to which the headline refers to, the source is not mentioned. However, the headline without stating the source can raise doubts of the readers, and those who do not read the text or read it only superficially may be misleaded.

Based on the so far presented results we can make a conclusion that the editors of front pages violate standards of truthful, impartial, balanced and fair reporting.

Second aim of the study is related to the compliance with the criteria of importance and usefulness of the information, and with the social responsibility of the media. Within this objective, we have defined two criteria: criteria of importance of the information and the criteria of social responsibility. Before we present the results of this research, it is important to emphasize that it was difficult to be completely objective in assessing the extent of the importance and usefulness of the information, because there are always information important to someone. However, regardless to that, we tried to be as objective as possible. The front page analysis with the criteria of usefulness of the information has shown that Jutarnji list published 134 headlines $(31,60 \%)$ related to completely insignificant news or information, Večernji list published 148 headlines of such sort (31,69\%), and 24 sata 142 of them, respectively $87,65 \%$. Front pages of Jutarnji list published 290 headlines informing on useful doings $(68,40 \%)$, front pages of Večernji list published 319 of them $(68,30 \%)$ and 24 sata only 20 headlines of such sort $(12,35 \%)$.

Table 5. Headlines based on the criteria of usefulness of information

\begin{tabular}{|c|c|c|c|}
\hline Daily newspaper & Jutarnii list & Večernji list & 24sata \\
\hline Total of headlines & 424 & 467 & 162 \\
\hline Useless information & 134 & 148 & 142 \\
\hline SHARE & $31,69 \%$ & $31,69 \%$ & $87,65 \%$ \\
\hline
\end{tabular}

Fourth aim of the research is related to the selection of news. We are the witnesses of worrying phenomenon in contemporary journalism where more media space is being occupied by bad news. Such journalism contributes to the growth of social apathy because people get impression that there is no more goodness, truth, justice, love, etc. If we set a question on why media thematise mostly "black" news, on the first place we should put the desire for circulation, or earnings. In order to answer the third research question, we researched following categories: good news, bad news and neutral news. We analysed 1053 headlines of which 555 (53\%) relate to the bad news, 100 headlines (9\%) good news and $398(38 \%)$ relate to the news that were not categorised as good or bad, which means they were neutral. If we analyse the headlines of each daily newspaper, the results are as follows: most headlines with bad news were published by 24 sata $(55,56 \%)$, followed by Večernji list with $53,32 \%$ and Jutarnji list with $50,94 \%$. Therefore, in these three daily newspapers more than $50 \%$ of bad news was published. If we take a look at the share of good news, the results are as follows: Večernji list published 12,63\% of such headlines, Jutarnji list 8,02\%, and 24 sata only 4,32\%.

Table 6. Headlines based on the criteria of good news - bad news

\begin{tabular}{|c|c|c|c|}
\hline Daily newspapers & Jutarnji list & Večernji list & 24sata \\
\hline Total of headlines & 424 & 467 & 162 \\
\hline Share of bad news & $50,94 \%$ & $53,32 \%$ & $55,56 \%$ \\
\hline
\end{tabular}

Besides from reporting on the principle that "bad news is good news" where we get the impression that everything is "black", this sort of reporting tries to manipulate the readers. The reason for such a reporting is the omnipresent hopelessness and fear in society. Each day, the readers are "bombarded" with the headlines of bad news, they get the impression that the bad prevails in the society, which can result in creation of irrational fears, especially with the 
emotionally immature readers, first of all with the children.

When proving the last aim of the research, we took in consideration the criteria of politeness, good taste and protection of privacy. We determined two criteria for the research: bad taste including obscenity and violation of privacy. 424 analysed headlines from Jutarnji list $(5,66 \%)$ can be characterised as headlines containing the elements of bad taste and obscenity. Večernji list published $1,71 \%$ of them, 24 sata alarming $50,61 \%$. Violation of privacy was found at 28 headlines (7\%) in Jutarnji list, 20 headlines (4\%) in Večernji list and 37 (24\%) in 24 sata.

Table 7. Headlines based on the criteria of bad taste and obscenity

\begin{tabular}{|l|c|c|c|}
\hline Daily newspapers & Jutarnji list & Večernji list & 24sata \\
\hline Total of headlines & 424 & 467 & 162 \\
\hline Share of headlines containing elements of bad taste or obscenity & 5,66 & $1,71 \%$ & $50,61 \%$ \\
\hline
\end{tabular}

Table 8. Headlines based on the criteria of violation of privacy

\begin{tabular}{|l|c|c|c|}
\hline Daily newspapers & Jutarnji list & Večernji list & 24sata \\
\hline Total of headlines & 424 & 467 & 162 \\
\hline Share of headlines violating the privacy & $7,00 \%$ & $4,00 \%$ & $24,00 \%$ \\
\hline
\end{tabular}

\section{Conclusion}

Headlines are the beginning of the communication between the newspapers and the reader. Based on the headline, we often bring the decision whether we are going to buy newspapers and reach for the content. Although the headline is often in discordance with the content, headlines affect our perception of content, especially if we have in mind that text is often being treated superficially. We should not forget that there are disinterested and superficial readers which read only headlines and form their beliefs and attitudes exclusively based on it. We can notice the tendency of headlines to be longer and become real small texts. However, the most concerning is the lack of ethics and entitlement.

Research on violation of ethic and professional standards of journalism at the example of analysis of three most read daily newspapers in Croatia has confirmed that front page editors neglect the criteria of truthfulness, fairness, impartiality and balance. The question is how is it possible? Who is responsible for such a paradox situation in journalism? It would be wrong to blame only journalists, editor and the owners and to neglect the responsibility of readers. On the one hand, editors "tail" headlines the readers are looking for, and on the other hand, readers get what is in conformity with their expectations. This is how it creates a vicious circle of unethical journalism from which the exit is not easy at all. Is the fact that "this is what people are looking for" and "it sells newspapers" sufficient to neglect ethic principles and professional standards of journalism? It is evident that editors and journalist, regardless to the legal regulations and ethical codes, do not realise the importance of respecting the ethical principles for the survival and positive role of journalism in building and preserving social values. Sometimes, the problems are legal regulations which are incomplete. In example, Article 7 of Media law regulating questions of privacy protection says that "the person who attracts the attention of the public by with its statements, behaviour and other acts related to its personal and family life, cannot demand the same level of protection as other citizens." Does this mean that such a person can be "stretched" in media indefinitely, even when it can result in serious consequences? What happens with emotionally misbalanced person? What about children? Legal provisions regulating the issue of media freedom should surely be more clear and precise. However, both public and media are very sensitive when it comes to the freedom of media. Regardless to it, some limitations must be set. Media freedom must not be absolute. The interest of public or the public good should be the measure for this freedom. The need to improve legal provisions or stricter application of existing provisions appears here, as well as the need for professional journalist regulation through the foundation of media councils. Self-regulation of journalism should start with the awareness of journalist or editor. The readers should act the same way and they should be raised for the media. In this respect, it would be necessary to undertake a broad social campaign which would include schools, associations of civils, scholars and media themselves.

If we try to give a reasonable response to the question how to be ethical journalist, we should say that an important role is to be attributed to the legal regulations, self-regulations and ethical codes, but it is not enough. These elements can be called the elements of external compulsion which should keep journalists within the frames of ethics. Meanwhile, we consider that the journalists must enter to sort of interaction with himself and to reassess his attitude to his job, which means his relation to man and society in general. It is very important not to forget the question: am I a good journalist? 


\section{References}

Bauer, T.A. (2007.) Mediji za otvoreno društvo, Zagreb: Sveučilišna knjižara

Bertrand, C.J. (2007.) Deontologija medija, Zagreb: Sveučilišna knjižara

Frankena, W.K. (1998.) Etika, Zagreb: Kruzak

Hanson, E. Ralph., (2014), Chapter 14. Media Ethics: Thruthfulness; Fairness, and Standards of Decency. [Online] Available: http://www.cqpress.com/docs/college/Hanson\%204e\%20Mass\%20Com\%20CH\%2014.pdf (May 10, 2015)

Ivas, I. (2004.) «Tropi u novinskim naslovima», Medijska istraživanja, vol.10 (2), 9-34

Kunczik, M., Zipfel, A. (1998.) Uvod u publicističku znanost i komunikologiju, Zagreb: Zaklada Friedrich Ebert

Labaš, D., Grmuša, T. (2011.) «Istinitosti i objektivnost u informaciji i društveno štetne komunikacijske forme», Kroatologija, vol.2 (2), 87 122

Malović, S. (1997.) «Profesionalizam - preduvjet objektivnog i poštenog novinarstva», Politička misao, vol.34 (4), 151-165

Malović, S. (2007.) Mediji i društvo, Zagreb: Sveučilišna knjižara

Petriševac, D. (2009.) «Obilježja novinskih naslova», Hrvatistika, vol.3 (3), 31-38

Street, J. (2003.) Masovni mediji, politika i demokracija, Zagreb: Politička misao

Vilović, G. (2004.) Etički prijepori u Globusu i Nacionalu 1999-2000., Zagreb: Fakultet političkih znanosti

Vilović, G. (2011.) «Novine», u: Peruško, Z. (ur.), Uvod u medije, Zagreb: Naklada Jesenski i Turk

Ward, Stephen, J.A., (2015), Global media Ethics. University of Wisconsin: Center for Journalism Ethics. [Online] Available: https:/l ethics.journalism.wisc.edu/resources/global-media-ethics/(May 10, 2015)

Ward, Stephen, J.A., (2015), Nature of Journalism Ethics.//Research ethics/. Center for Journalism Ethics School of Journalism \& Mass Communication: University of Wisconsin - Madison. [Online] Available:http://www.journalismethics.info/research_ethics/nature_ of_journalism_ethics.htm (May 10, 2015)

Wojtyla, K. (1998. ) Temelji etike, Split: Verbum

Zgrabljić-Rotar, N. (2007.) Radio - Mit i informacija, dijalog i demokracija, Zagreb: Golden marketing

Zakon o medijima., (2015), [Online] Available: http://www.zakon.hr/z/38/Zakon-o-medijima (13.11. 2014) 


\title{
The Phenomenon of Arab Spring in the Middle East
}

\author{
Wan Kamal Mujani \\ The National University of Malaysia \\ Email: inamal@yahoo.com \\ Siti Nurul Izah Musa \\ The National University of Malaysia \\ Email: nurulizah_89@yahoo.com
}

\section{Doi:10.5901/mjss.2015.v6n4s2p152}

\begin{abstract}
The term Arab Spring or its Arabic term, al-Rabi' al-'Arabi is the revolution of demonstrations and protests of the people against the ruling Government. It was claimed to begin on December 18, 2010 in Sidi Bouzid, Tunisia. However, this outbreak also spreads to several other Western Asian countries such as Egypt, Libya, Yemen and Syria. As such, this article aims to analyze the phenomenon of Arab Spring happening in those countries. This article also aims to explore how the outbreak of the unrest occurred and identify the factors that led to the protests of the people as well as to review the role of mass media in the revolution of the people. This study uses a qualitative method which is a document analysis approach to synthesize information from authoritative resources to ensure the validity of the information obtained. The study found that the wave of revolution was the people's protests against the current ruling Government. Several factors such as political, economic, and social factors are the main cause leading to the phenomenon of Arab Spring. Although this may be attributed to issues or problems that vary for each country, the goal of the rise of the people remains the same, i.e. protesting against unfair Government and demanding that people's rights be reinstated.
\end{abstract}

Keywords: Arab spring; revolution; upheavals; Middle East;

\section{Introduction}

The rise of the people that broke out in the Arab world due to political conflict has attracted the attention of the public. This issue is no longer alien in countries that previously ignored and isolated themselves from the political development of the world. The people's uprise which began in Tunisia in December 2010 that triggered people's revolt then spread to Egypt and Libya and protracted to other Arab countries. However, this event has started around two years earlier, in Yemen in 2009 and Bahrain in 2010. Nonetheless, both uprises seemed ignored and overlooked as the protests only occurred on a small scale. Most of the events have one similar purpose, to demand for a fair and equitable ruling. Thus, indirectly, this is one of the factors leading to the uprise and the people sought for a transformation that would take place in their country. In addition, the mass media is also seen to be the most effective medium not only to disseminate information, but also as a medium of communication to uplift the spirit of the people to rise against the leading of the reign (Haas, 2013).

\section{The term 'Arab Spring'}

The wave of revolution, or more popularly known as the Arab Spring, refers to rebellion that occurs among people. This uprise is the voice of the people demanding their rights to be reinstated from the current ruling Government. Arab Spring or in Arabic term al-'Arabi al-Rabi' is the people's protests against the injustice of the ruling system and demand for a more democratic new government. The people seemed to just realize that all this while they had been oppressed and their rights had been denied, thus, they oppose the current existing leaders. When people are not allowed to speak, street demonstrations are the only alternative. The government regime treated this similarly as to what happened in Palestine as the people who fought against the Zionist were considered terrorists and against peace. The turmoil of the Arab world has impacted the rest of the world (Gordon, 2010). 